\title{
Liselere Öğretmen Yetiştirmede Geri Adım: Yüksek Öğretmen Okullarından Pedagojik Formasyon Kurslarına
}

\author{
Şule AYCAN \\ Muğla Sitkı Koçman Üniversitesi Eğitim Fakültesi, İlköğretim Bölümü \\ E-mail:suleaycan@mu.edu.tr
}

\begin{abstract}
$\ddot{O}_{z e t}$
Bu çalışmada Cumhuriyet öncesi kurularak 1970'li yıllara kadar ülkemizin lise öğretmeni gereksinimi sağlayan Yüksek Öğretmen Okullarl; tarihsel gelişimi, öğrenci profili ve mezunlarının özellikleri bakımından tanıtılmıştır. Bu okulların ögrenci kaynağı olan İlköğretmen Okullarının öğretmenlik meslek derslerinin haftallk ders saatleri, kapatılan Anadolu Öğretmen Liseleri ve pedagojik formasyon kurslarınınki ile karşılaştırllmıştır. Ayrıca günümüzde lise öğretmeni yetiştirmek amacıyla açılan pedagojik formasyon kurslarının öğretmen yeterliklerini ne derecede karşılayacağı incelenmiștir. Bazı ülkelerin ögretmen yetiștirme programlarındaki gelişmeler verilirken liselere ögretmen yetiștiren Eğitim Fakültelerinin Ortaöğretim Fen ve Matematik Ĕ̆itimi (OFMA) ile Ortaöğretim Sosyal Alanlar Ĕğitimi (OSA) Bölümlerine öğrenci alımının durdurulması sorgulanmıştır. Çalışmada betimsel yöntem kullanılmış olup, kaynak olarak bilimsel literatür ve yazılı basından yararlanılmıştır.
\end{abstract}

Anahtar kelimeler: öğretmen yetiştirme, yüksek öğretmen okulu, pedagojik formasyon kursu

\section{Step Back in Educating High School Teachers: From Higher Teacher Education School to Pedagogical Formation Course}

\begin{abstract}
In this study, Higher Teacher Education Schools have been analyzed in terms of their historical development, student profile and graduated quality. These schools have been established provided requirement of high school teachers of our country from last years of Ottoman Empire to 1970's. Student sources of Higher Teacher Education Schools were Training Colleges. Weekly teaching courses of Training Colleges have been compared with Anatolian Teacher Training High Schools and pedagogical formation courses. In addition, it has been investigated, effects of pedagogical formation courses for train high school teachers to teacher qualification. Growing of teacher training programs of some countries were surveyed and, being stopped of student admission to Science and Mathematics Education Departments and Social Fields Education Departments of Education Faculties were examined. In this paper, descriptive method has been used and it has been benefited from scientific literature and printed media.
\end{abstract}

Key words: teacher training, higher teacher education school, pedagogical formation course

\section{Giriş}

Yüksek Öğretmen Okulları, lise ve dengi okullara öğretmen yetiştiren eğitim kurumlarıdır. Okulun tarihinin, Dârülmuallimîn adlı okulun açılış tarihi olan 16 Mart 1848'e kadar uzandığı kabul edilmektedir. Dârülmuallimîn zaman içinde geliştirilerek, bünyesinde ilk, 
orta ve liselere öğretmen yetiştiren kısımları da kapsayan Dârülmuallimîn-i Âliye adlı kuruma dönüşmüş, 1891 yılında bu kurumun içinde yer alan 'Âli' kısmı bugünkü lise düzeyindeki okullar olan idâdilere öğretmen yetiştiren bir yüksekokul haline getirilmiştir (Eşme, 2001).

Cumhuriyetin ilk yıllarında yapılan çalışmalarla, Yüksek Muallim Mektebi adını alan okul, "Ecole Normale Superieure" adlı Fransız Yüksek Öğretmen Okulu'nu kendine model olarak almıştır (Eşme, 2003). École Normale Supérieure, Fransa'nın en prestijli yükseköğrenim kurumudur. Dünya çapında en başarılı öğrencilerin son derece ağıı sınavlardan geçerek alındıkları okulda Fransa'nın en önemli bilim adamları ve filozofları ders vermiştir. Okulun önde gelen mezunlarından Nobel Edebiyat ödülünü 1915'de Romain Rolland, 1927'de Henri Bergson ve 1964'de Jean-Paul Sartre almışlardır. Okulun mezunlarından Nobel Fizik Ödülünü alanlar 1908'de Gabriel Lippmann, 1921'de Alfred Kastler, 1926'da Jean-Baptiste Perrin, 1970'de Louis Néel, 1991'de Pierre-Gilles de Gennes, 1997'de Claude Cohen-Tannoudji ve 2007'de Albert Fert'tir. Paul Sabatier ise 1912 yılında Nobel Kimya Ödülünü almıştır (http://tr.wikipedia.org/wiki/ \%C3\%89cole _Normale_Sup\%C3\%A9rieure).

Liselere öğretmen yetiştiren İstanbul'daki Yüksek Muallim Mektebi, 1956'ya kadar tek kurum olarak kalmıştı. Bu okul nitelikli öğretmenlerin yetiştirilmesinde önemli bir rol oynamıştır. Ancak, yıllık mezun sayısı bazı yıllar 30'a bile varamamış, 1923-1963 arasında toplam 630 mezun verebilmiştir (Akyüz, 2004). 1934‘de, Yüksek Muallim Mektebi'nin, Cumhuriyet dönemindeki yapılanması başlangıç düşünülerek, onuncu kuruluş yıl dönümü kutlanmıştır. Bu tarihte okulun adındaki Arapça kökenli sözcükler değiştirilerek artık okul Yüksek Öğretmen Okulu olarak isimlendirilmiştir. Bu kurum, 1959'a kadar liseyi bitirerek Üniversitenin Fen ve Edebiyat Fakültelerine giren öğrencilerden sinavla seçim yaparak öğrenci alıyordu. Yüksek Öğretmen Okulu 1930’lu yılların ortalarında, okulun hedefi olan Fransız Yüksek Öğretmen Okulu niteliğindeki yapıya çok yaklaşmıştır. 1930 ve 40 'lı yıllarda, tıp fakülteleri dâhil, üniversitelerin pek çok bölümüne sınavsız öğrenci alınırken, Yüksek Öğretmen Okulu, sınavla öğrenci alan bir-kaç okuldan biri durumundadır. Dahası, okulun bu niteliği nedeniyle, o yıllarda liselerin başarısının, Yüksek Öğretmen Okuluna sokabildikleri öğrenci sayısı ile ölçüldüğü eğitimciler tarafından hep dile getirilmiştir. Okulun bu başarısında şüphesiz öğretim kadrosunun etkisi büyük olmuştur. Lisans derslerini İstanbul Üniversitesinde gören öğrenciler, akşamları dönemin en seçkin eğitimcilerinden meslekleriyle ilgili ek dersler almışlardır. Prof. Z. Fahri Fındıkoğlu, Sadrettin Celal Antel, Prof.Cemil Bilsel, Prof.Mazhar Osman, Prof.Besim Darkot bu kadroda yer alanlardan ilk akla gelen isimlerdir. Yüksek Öğretmen Okulu, bir bakıma altın dönemini yaşadığı bu yıllarda, Türk Millî Eğitimine daha ileriki yılarda yön verecek mezunlar vermiştir. Arif Akçabay, Mesut Talaslıoğlu, Kamil Günel, Selman Erdem, Hasan Erk, Behçet Necatigil, Orhan Dengiz, Nuri Kodamanoğlu, Selman Erdem ve Turan Birinci bunlar arasında yer alır.

Giderek gelişen ve yıldızı parlayan Yüksek Öğretmen Okulu, 1946 yılında kötü bir gelişme ile yüz yüze gelir. 12 Haziran 1946 tarihinde çıkarılan üniversiteler yasası, öğretim üyelerinin üniversite dışında görev almasını yasaklamıştır. Bu gelişme, Yüksek Öğretmen Okulu için bir dönem noktası olmuştur. Söz konusu yasa ile okulda eğitimin niteliğinin artmasında önemli rolü bulunan müzakereci akademik kadronun okulla ilişkisi kesilmiştir. Okul, bu gelişmenin ardından bir öğrenci yurduna dönüşme sürecine girmiştir. Gelişen olumsuzluklar, 1949-1950 yılı başında okulun kapatılmasına kadar uzanır. Okul 2 yıl sonra, 1 Mart 1951'de, tarihi ve görkemli bir mekân olan Çapa'daki binada eğitime yeniden başlar. Yüksek Öğretmen Okulu, kapalı kaldığı iki yıl içinde, önemli ölçüde prestij kaybetmiştir. 1940'll yıllarda lise mezunlarının, öğrencisi olmaya can attı̆̆ okul 1950'li yıllarda eski çekiciliğini yitirmiş, her yıl verebildiği 3-5 mezunla öğretmen ihtiyacını gidermede yetersiz bir duruma gelmiştir. 
Lise öğretmeni yetiştiren tek kaynak durumundaki Yüksek Öğretmen Okulu'nun verdiği mezun sayısındaki gerilemenin tersine, 1950'li yıllarda, sanayileşmenin hız kazanmasıyla köyden kente göçün başlaması nedeniyle lise ve lise öğrenci sayısında önemli bir artış başlar. Öte yandan, Türkiye'de bu yıllarda mühendislik dallarının gözde meslek olmaya başlaması Yüksek Öğretmen Okulunun çekiciliğini olumsuz etkilemiş, sonuçta okul nitelikli öğrenci bulmada eski gücünü yakalayamamıştır (Eşme, 2001). Bu gelişme, dönemin eğitimcilerini, lise öğretmeni yetiştirmede yeni bir öğrenci kaynağ aramaya yöneltir.

1950'li yılların sonlarında ülkede 52 ilköğretmen okulu vardı. Bu okulların 21'i Köy Enstitülerinin devamı niteliğinde olup eğitim süresi 6 yıldı. 1958-1959 döneminde ilköğretmen okullarında, \%75'i köy çocuğu olmak üzere 19835 öğrenci bulunmaktaydı. O tarihlerde ilköğretmen okulları, askeri okullar gibi parasız yatılılık imkânları en geniş olan eğitim kurumları durumundaydı. Bunun sonucu olarak öğretmenlik mesleği Cumhuriyet döneminden 1960'lı yılların sonlarına kadar özellikle köy çocuklarının okuması için tek seçenekti. Gerçekte onlar başka meslekleri de çok iyi tanımamaktadırlar. Dolayısıyla her köy çocuğunun gönlünde öğretmenlik büyük bir ideal olarak yaşamaktadır. Ancak bu ideale erişilmesi o kadar kolay değildir. Çünkü her ilçe bünyesindeki köylerden ancak bir iki kişi bu okullara girebilmekteydi.

52 öğretmen okulunda eğitim gören; üstün meslek motivasyonu kazandırılmış, yetenekli daha da önemlisi öğretmenlik mesleğinin erdemlerini küçük yaşlarda kavramış bu öğrenciler, Yüksek Öğretmen Okullarına yeni öğrenci kaynağı olabilirler miydi?

1950'li yıllarda lise öğretmenine duyulan ihtiyacın giderek artması karşısında, 1959'da Ankara'da yeni bir Yüksek Öğretmen Okulu açılmıştır. Bu yeni okulun sistemi, ilköğretmen okullarının en başarılı ve seçkin öğrencilerini alma esasına dayalı yeni bir modeldi. Söz konusu model, kuşkusuz geleneksel Yüksek Öğretmen Okulunun devamı niteliğindeydi. Ancak bu model, İstanbul'da bulunan Yüksek Öğretmen Okulunun aksayan yönlerinin yeniden gözden geçirilmesi ile oluşturulmuş bir modeldi. Yeni modelin en can alıcı ve niteliği arttırıcı özelliği, öğrencilerini ilköğretmen okulu son sınıfına geçmiş öğrencilerden seçerek alması ve okulun öğrencilere dal öğrenimi ile ilgili dersleri üniversitenin ilgili fakülte ve bölümlerinde aldırmasıydı (Uygun, 2006).

Liselere öğretmen ihtiyacının karşılanması amacıyla 1965 yılında İzmir Yüksek Öğretmen Okulu, Ankara Yüksek Öğretmen Okulu modeline uygun olarak hizmete girmiştir.

Ankara Yüksek Öğretmen Okulu modeli, tüm tartışmalara rağmen 1972 yılına kadar korunmuş; 1972 yılında çıkarılan Yüksek Öğretmen Okulları Yönetmeliği ve 1973 yılında çıkarılan 1739 sayılı Millî Eğitim Temel kanunuyla önemli değişmelerle karşı karşıya kalmıştır.

1972 yılında çıkarılan Yüksek Öğretmen Okulları Yönetmeliği’ne göre okula; üniversitelerde okuyan öğrenciler arasından burslu öğrenci alınabileceği hükmü getirilmiştir. 1973'te yayımlanan 1739 sayılı Millî Eğitim Temel Kanunu'nun İlköğretimi sekiz yıla çıkarma ve buna uygun öğretmen yetiştirme isteği öğretmen yetiştirme sisteminde önemli değişikliklere sebep olmuştur. Kanunun uygulamasında öncelikle öğretmen yetiştirmeye yükseköğrenim şartı getirilmiş, İlköğretmen Okulları kapatılarak Öğretmen Liselerine dönüştürülmüştür. Bu uygulama ile "Yüksek Öğretmen Okulu" bünyelerindeki "Hazırlık Sınıfları" işlevlerini yitirmiştir. Bu gerekçe ile 1974-1975 öğretim yılından başlayarak "Yüksek Öğretmen Okulu" bünyelerindeki "Hazırlık Sınıfları" uygulamasına son verilmiştir. Böylece Yüksek Öğretmen Okullarının hazırlık sınıflarının İlköğretmen Okullarından özenle seçilen öğrenci kaynağı kurumuş; 10.9.1973 tarih ve 19475 sayılı Millî Eğitim Bakanlık emri ile hazırlık sınıfları İlköğretmen Okulu son sınıflarına dönüştürülmüştür. 1975 yılından itibaren hazırlık sınıflarının kapanması sonucu, farklı alanlarda okuyan nitelikli gençlerin Yüksek Öğretmen Okuluna çekilerek öğretmen olarak yetiştirilmesi amacıyla, üniversite imtihanını kazanmış lise mezunları arasından; açılan sınavlarla öğrenci alınmaya başlanmıştır. 1970’li yıllardan sonra 
bakanlık uygulama değiştirerek Yüksek Öğretmen Okulu öğrencilerini üniversite giriş sınavları ile almaya başlamıştır. Bunun anlamı Yüksek Öğretmen Okulunun kapılarını diğer fakültelere giremeyen lise mezunlarına açmak ve yetenekli ilkokul öğretmenlerinin ileri eğitim olanaklarını sinırlamaktır. Bakanlığın bu uygulaması nedeniyle Yüksek Öğretmen Okulu öğrenci sayısında düşme başlamıştır (Gelişli, 2001).

\subsection{Araştırma problemi}

Liselere öğretmen yetiştirmek için verilen Pedagojik Formasyon Kursları, katılımcılarını öğretmen yeterlikleri bağlamında geçen yüzyılın eğitim kurumları olan YüksekÖğretmen Okulları kadar başarılı öğretmen olarak yetiştirebilmekte midir?

\section{2. İlgili literatür}

Öğretmen yeterlikleri, öğretmenlik mesleğine karşı öğretmen adaylarının tutumları, Pedagojik Formasyon Kursları, çeşitli ülkelerin öğretmen yetiştirme modelleri ile ilgili çok sayıda yayın bulunmaktadır. Fakat Yüksek Öğretmen Okulları ile ilgili ne yazık ki fazla araştırma yoktur. $\mathrm{Bu}$ önemli modelin genç nesillere anlatılmasının önemli olduğu düşünülmektedir.

Türk Eğitim Derneği’nin hazırlattığı Öğretmen Yeterlikleri Özet Raporunda vurgulanan önemli ifadelerden bazıları şöyledir. "öğretmen eğitimi alan dışı atamalar ve geçici çözüm arayışlarına bağlı düzenlemeler ile yaz-boz tahtasına dönüşmüştür. Öğretmen yetiştirmede on yıl önce vazgeçilen bazı uygulamalara, on yıl sonra rasyonel hiçbir gerekçe olmadan geri dönülmüştür." "öğretmen eğitiminde bir kalite güvence ve akreditasyon sistemi oluşturulamamıştır." "Öğretmen yetiştiren yükseköğretim kurumlarında öğretim elemanı, fiziksel olanaklar ve teknolojik altyapı yetersizlikleri, çağın gerektirdiği yeterliklere sahip öğretmen yetiştirmeyi olanaksız kılmaktadır." (Öğretmen Yeterlikleri Özet Raporu, 2009)

Türkçe ve Türk Dili ve Edebiyatı öğretmen adaylarının öğretmenlik mesleğine ilişkin tutumları (Bozkırlı ve Er, 2011), Tezsiz yüksek lisans öğrencilerinin öğretmenlik mesleğine ilişkin tutumları (Özben, 2005; Aycan vd., 2005), Öğretmen adaylarının eğitim inançları ile öz yeterlik algıları arasındaki ilişki (Ilgaz vd., 2013), Öğretmen adaylarının öğretmenlik mesleğine yönelik tutumları (Özder vd., 2010), Eğitim Fakültesi ve Fen Edebiyat Fakültesi öğrencilerinin öğretmenliğe karşı tutumları (Aycan vd., 2010), Eğitim fakültesi öğrencileri ile tezsiz yüksek lisans öğrencilerinin öğretmenlik mesleğine yönelik tutumlarının karşılaştırılmalı incelemesi (Ocak ve Demirdelen, 2008), Ortaöğretim alan öğretmenliği tezsiz yüksek lisans öğrencilerinin öğretmenlik mesleğine yönelik tutumları (Başbay vd. 2009), Fen-Edebiyat fakülteleri ve formasyon programı (Ünüvar, 2012) gibi araştırmalarda öğretmenlik mesleğini benimseme ile ilgili değerlendirmeler yapılmıştır. Çelikten ve arkadaşları, öğretmenlik mesleğini ve özelliklerini açıklarken (Çelikten vd., 2005), Yüksel Fen-Edebiyat fakültesi öğretim üyelerinin öğretmen yetiştirilmesiyle ilgili görüşlerini incelemiştir (Yüksel, 2011). Araştırmaların bir kısmı da pedagojik formasyon öğrencilerinin çeşitli özellikleri üzerine yoğunlaşmıştır. Örneğin; pedagojik formasyon öğrencilerinin öğrenme stilleri (Güneş ve Gökçek, 2012), formasyon öğrencilerinin pedagojik formasyon programına ilişkin sahip oldukları metaforlar (Dündar ve Karaca, 2013), mesleki ve teknik eğitim fakülteleri öğrencilerinin pedagojik formasyon eğitimine ilişkin görüşleri (Gelişli, 2009) gibi çalışmalardır.

Yüksek Öğretmen Okulları ile ilgili çok fazla çalışma bulunmamaktadır. Bu konuda en önemli eser Yüksek Öğretmen Okulları isimli kitaptır (Eşme, 2001). Bu kitabın bir özeti de iki yıl sonra makale olarak sunulmuştur (Eşme, 2003). Bu iki eser, Yüksek Öğretmen Okulları ile ilgili çalışma yapanların temel başvuru kaynağıdır. Yüksek 
Öğretmen Okulları uluslararası bir kongrede dünyaya tanıtılırken (Aycan ve Aycan, 2013), ulusal kongrelerde genç nesiller bilinçlendirilmiştir (Aycan ve Aycan, 2009; Aycan, 2011).

\subsection{Araştırma yöntemi}

Bu çalışmada betimsel yöntem kullanılmıştır. Ülkemizde liselere öğretmen yetiştirmenin tarihi süreci; öğretmen yeterlikleri temel alınarak Yüksek Öğretmen Okulları ile günümüz Pedagojik Formasyon Kurslarının karşılaştırılarak ele alınmıştır. Çalışmada kaynak olarak bilimsel literatür ve yazılı basından yararlanılmıştır.

\section{Bulgular}

Birçok eğitim kitabında eğitimin istendik davranışların kazandırılması olduğu vurgulanmaktadır. $\mathrm{Bu}$ tanıma göre; istendik davranışlar kime göre, neye göre kazandırılmalıdır? Tek tip insan yetiştirmeden öteye gitmeyen bir eğitim modeli hiçbir şekilde savunulamaz (Aycan ve Aycan, 2011). Yüksek Öğretmen Okullarını bitirenlerin eğitim anlayışı ise, pozitif bilimlerin kılavuzluğunu kabul eden bir anlayıştır. Günümüz söylemlerinde yer alan "ezberci eğitime son verilmeli", "sorgulama temelli eğitim geliştirilmeli", "sınıf dışı eğitim özendirilmeli" gibi ifadeler, yıllar öncesinde Yüksek Öğretmen Okulu öğrencileri için sıradan kavramlardı.

Ülkemizdeki öğretmenlik mesleği genel yeterlikleri Tablo 1'de verildiği gibi altı yeterlik ve otuz bir alt yeterlikten oluşmaktadır (http://otmg.meb.gov.tr/YetGenel.html).

Benzer şekilde Avrupa Konseyinin 26 Ekim 2007 tarihli kararına göre öğretmenlerin sahip olması gereken yeterlikler de Tablo 2'de verilmiştir (TED, 2009).

Tablo 1 Türkiye'de öğretmenlik mesleği genel yeterlikleri

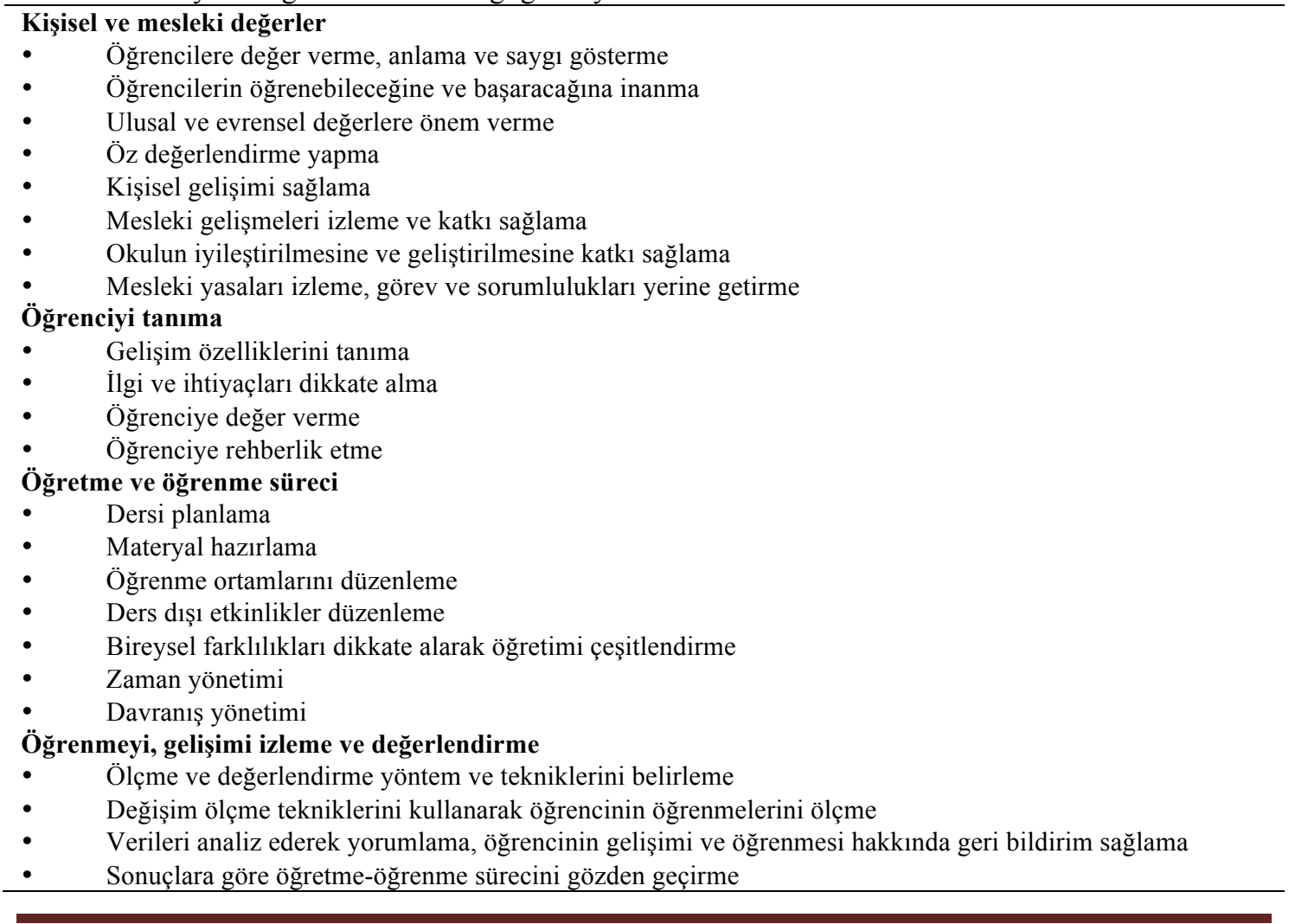




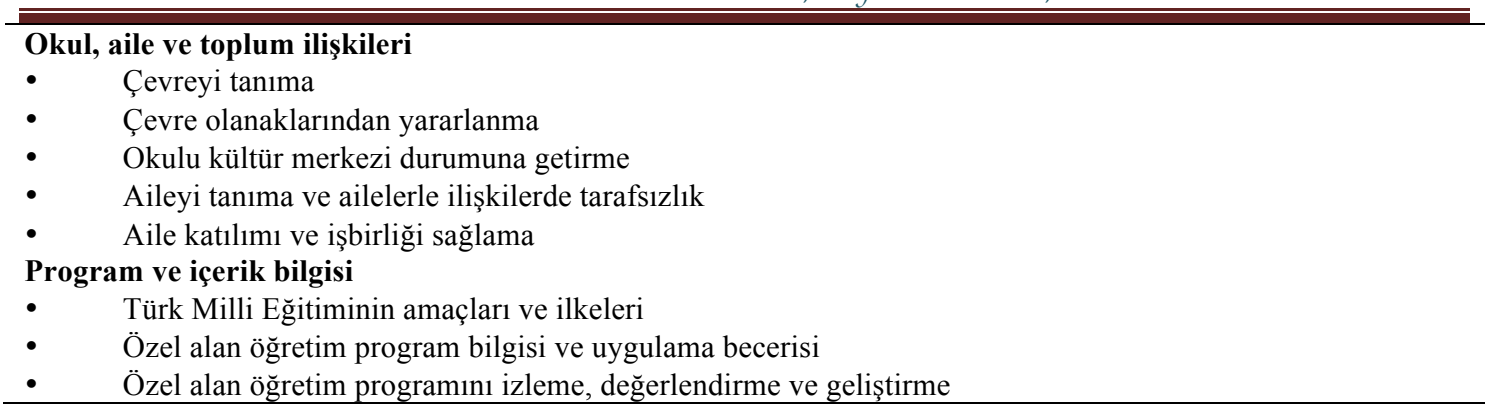

Tablo 2 Avrupa Konseyince belirlenen öğretmen yeterlikleri

- $\quad \mathrm{AB}$ temel beceriler dokümanında önerilen disiplinler arası becerilerin öğretimi

- Karşılıklı saygı ve işbirliğine dayalı, güvenli ve cazip bir okul ortamının oluşturulması

- $\quad$ Özel eğitim ihtiyaçları dâhil olmak üzere, farklı yetenek ve ihtiyaçlara sahip, farklı sosyal ve

kültürel çevrelerden gelen öğrencilerden oluşan heterojen sınıflardaki öğrencilere etkili olarak öğretebilme

- Meslektaşları, aileler ve daha geniş toplumsal çevre ile yakın işbirliği içinde çalışabilme

- $\quad$ Okul geliştirmeye katılma ve katkı sağlayabilme

- Sorgulayıcı araştırma ve uygulamalarla yeni bilgi geliştirme ve yenilikçi olma

- Mesleki gelişiminde ve çeşitli işleri yaparken bilişim teknolojilerini kullanma

- $\quad$ Kariyerleri süresince mesleki gelişimlerinde özerk bir öğretici haline gelme

Yüksek Öğretmen Okulu mezunları halen her yıl toplanıp ülkenin eğitim sorunlarını tartışmaktadırlar. Yüksek Öğretmenlilerin ülkenin eğitim sorunları hakkındaki görüşleri önemlidir. Aycan'ın (2011) araştırmasına göre: şu an en önemli eğitim sorunumuz nedir, sorusuna verdikleri yanıtlar önem arz etmektedir. Bu yanıtlara göre en belirgin eğitim sorunları aşağıdaki gibi sıralanabilir: eğitimin amacı belli değil, eğitim sistemi sürekli değişiyor, bize özgü bir model yok, ezberci eğitim, sınıflarda öğrenci sayıları fazla, eğitim kalitesiz, test sınavları başarıyı ölçmede yetersiz, düşünen, sorgulayan insan yetiştirilmiyor, temel bilimler eğitimi yetersiz, pozitif düşünce kazandırılmıyor, sınav sistemi uygun değil, özgüveni olmayan, bilgi hamalı kişiler yetiştiriliyor, uygulamalar yetersiz, ilk ve ortaöğretimde sınıf geçmek çok kolay, eğitimin önemi bilinmiyor, eğitim fakültelerinin programları yetersiz, öğretmenler iyi yetişmiyor, eğiticiler eğitimsiz.

$\mathrm{Bu}$ sorunun nasıl çözüleceğine verilen yanıtlardan birinci sırada Devlet politikaları (\%37) ve kurumlar (\%37) gelmekte olup bunu kişi-kurum-Devlet işbirliği (\%17) izlemektedir (Aycan, 2011).

Günümüzde liselere öğretmen yetiştirme amaciyla eğitim fakülteleri bünyelerinde pedagojik formasyon kursları açılmıştır. 2000'li yıllarda fen-edebiyat fakültesi mezunları için Tezsiz Yüksek Lisans uygulaması vardı. Bu uygulamaya göre, alınacak öğrencilerin yüksek lisansa başlama koşullarına sahip olmaları gerekiyordu ve bu uygulama bir yüksek lisans programı olduğundan ilgili dersleri doktora derecesi olmayan öğretim elemanları veremiyordu. Tezsiz yüksek lisans eğitimi uygulamadan kaldırılıp, 90'lı yıllardaki formasyon kurslarına dönülmüş ve öğrenci alımında da mezuniyet not ortalaması en önemli etken olmuştur. Bağıl sistem denilen ve bir öğrencinin aldığ 1 derslerin \% 70'ini bilmeden geçtiği bir uygulamada, öğretmen adaylarının niteliği için ne söylenebilir? Son dönemde pedagojik formasyon kurslarına öğrenci alımında ALES notunun payının da olması, az da olsa öğretmen adayı kalitesi için bir umut doğurmuştur.

Liselere öğretmen yetiştiren Yüksek Öğretmen Okullarının öğrencileri ise gerçekten öğretmen olmak isteyen çalışkan öğrencilerdi. Eskiden üniversiteye girebilmek için lise mezunu olmak gerekiyordu. Yani herhangi bir meslek lisesi mezunu ayrıca lise bitirme sınavlarına girmeden üniversiteye kaydolamaz, üniversite sınavlarına giremezdi. Yukarda belirtilen 3 ya da 6 yıllık ilköğretmen okullarında öğrenim gören öğrencilerden son sınıfa 
geçen çok az sayıdaki çalışkan ve iyi ahlaklı birkaç öğrenci Yüksek Öğretmen Okuluna seçilirdi. Burada bir yıl Hazırlık Sınıfı okunurdu. Hazırlık sınıfı, şimdiki anlamıyla bir yabancı dil sınıfı değildi. Burada Lise Son Sınıf bilgileri alınır, ders aralarında ise lise birinci ve ikinci sınıf bilgileri ögretilirdi. Bu bir yılın sonunda Lise Bitirme Sınavına girilerek lise diploması alınır ve üniversite sınavına girmeye hak kazanılırdı. Hazırlık sınıfında başarılı olamayanlar, geldikleri ilköğretmen okuluna geri giderek bir yıl daha öğretmen okulu son sınıfı okuyarak ilkokul öğretmeni olurlardı. Örneğin; İzmir Yüksek Öğretmen Okulunda sadece üniversitenin fen bölümlerinde okuyacak öğrenciler vardı. Dolayısıyla hazırlık sınıfında yoğun bir fen programı uygulanıyordu. Hazırlık sınıfını başaranlar da sadece Ege Üniversitesi Fen Fakültesinin Fizik, Kimya, Biyoloji ve Matematik bölümlerine girebiliyordu. Üniversitede dört yıl ilgili eğitim görülürken, akşamları da uzman öğretmenlerden eğitim dersleri alınıyordu. Aslında bu dersler bir bakıma Öğretmen Okulunda alınan Öğretmenlik Meslek Derslerinin unutulmamasını sağlarken ayrıca liselerde de öğretmenlik uygulaması yapılıyordu. Öğretmen okullarında verilen öğretmenlik meslek dersleri 1932-1937 yılları için Tablo 3'de ve 1937-1953 yılları için Tablo 4'de verilmiştir (Kavak vd., 2007).

Tablo 3 İlköğretmen Okulu 1932-1937 programı meslek dersleri haftalık ders dağı̆tım çizelgesi

\begin{tabular}{|lcccc|}
\hline \multicolumn{1}{r}{ DERSLER } & \multicolumn{2}{c}{ SIIFLAR } & \multirow{2}{*}{ TOPLAM } \\
\cline { 2 - 4 } & $\mathbf{1}$ & $\mathbf{2}$ & $\mathbf{3}$ & \\
\hline Terbiye ve Ruhiyat & 2 & 2 & 2 & 6 \\
Felsefe, İçtimaiyat & - & - & 3 & 3 \\
Tedris Usulü & - & 2 & 7 & 9 \\
Ders toplam & & & & $\mathbf{1 8}$ \\
\hline
\end{tabular}

Tablo 41 İlköğretmen Okulu 1937-1953 meslek dersleri haftalık ders dağıtım çizelgesi

\begin{tabular}{|lcccc|}
\hline \multicolumn{1}{c}{ DERSLER } & \multicolumn{2}{c}{ SIIFLAR } & TOPLAM \\
\cline { 2 - 4 } & 1 & 2 & 3 & 3 \\
\hline Pedagoji & - & 2 & 1 & 4 \\
Psikoloji & 2 & 2 & - & 2 \\
Psikoloji & - & - & 2 & 9 \\
Tedris Usulü ve Tatbiki & - & 2 & 7 & 2 \\
Sosyoloji & - & - & 2 & $\mathbf{2 0}$ \\
Ders toplam & & & & \\
\hline
\end{tabular}

İlk öğretmen okullarının öğretim süresi 1970-1971 yılma kadar ortaokul üzerine üç yıl iken, 18 Mart 1970 tarihinden itibaren ilkokul üzerine yedi yıl, ortaokul üzerine dört y1l öğretim vermeleri kararlaştırılmıştır. Böylece lise programının yanında pedagojik formasyon derslerinin sayı ve kapsamı genişletilmiştir. 1970-1974 yılları için Tablo 5'de verilmiştir.

Tablo 5 1970-1974 meslek dersleri haftalık ders dağıtım çizelgesi

\begin{tabular}{llcccc}
\hline DERSLER & \multicolumn{3}{c}{ SINIFLAR } & TOPLAM \\
& I & II & III & IV & \\
Psikoloji & - & 2 & - & - & 2 \\
\hline
\end{tabular}


ISSN 2148-6999 Cilt-Volume 2, Sayl- Number 2, 2015

\begin{tabular}{llllll}
\hline \hline Eğitim Psikolojisi & - & 3 & 2 & - & 5 \\
Eğitim Sosyolojisi & - & - & - & 2 & 2 \\
İlkokullarda Öğretim & - & - & 4 & 4 & 8 \\
İlkokullarda Yönetim & - & - & 1 & - & 1 \\
Seçmeli Meslek Dersleri & - & - & 1 & 1 & 2 \\
Felsefe (Sos. Man. Fel.) & - & - & 6 & 6 \\
Ders toplam & & & & & $\mathbf{2 6}$ \\
\hline
\end{tabular}

Tablo 3, 4 ve 5'ten görüldüğü gibi öğretmenlik meslek derslerine ilerleyen y1llarda daha çok önem verilmiştir.

Günümüzün Anadolu Öğretmen Liselerinin öğretmenlik meslek dersleri bakımından haftalık ders çizelgeleri Tablo 6'da verilmiştir (http://www.muallimce.com).

Tablo 6 Anadolu Öğretmen Liselerinin meslek dersleri haftalık ders dağıtım çizelgesi

\begin{tabular}{llclll}
\hline DERSLER & $\mathbf{9}$ & SINIFLAR & \multicolumn{1}{c}{ TOPLAM } \\
Felsefe & - & $\mathbf{1 0}$ & $\mathbf{1 1}$ & $\mathbf{1 2}$ & 2 \\
Öğretmenlik M Giriş & - & 2 & - & - & 2 \\
Türk Eğitim Tarihi & - & - & - & 1 & 1 \\
Eğitim Psikolojisi & - & 2 & - & - & 2 \\
Eğitim Sosyolojisi & - & - & - & 2 & 2 \\
Psikoloji (Seçmeli) & - & 2 & - & - & 2 \\
Sosyoloji (Seçmeli) & - & - & - & - & 2 \\
Mantık (Seçmeli) & - & - & - & 2 & $\mathbf{1 5}$ \\
Ders toplam & & & & & \\
\hline
\end{tabular}

Tablo 3, 4 ve 5 incelendiğinde ilerleyen y1llarda öğretmenlik meslek derslerinin saatlerinin arttırıldığı görülmektedir. İlköğretmen okullarının son sınıfına geçmiş, Yüksek Öğretmen Okulu hazırlık sınıfına seçilen öğrenciler için öğretmenlik meslek dersleri haftalık ders saatleri (son sınıflar dışında) 1932-1937 programında 6 saat, 1937-1953 programında 8 saat ve 1970-1974 programında 13 saattir.

Günümüzde verilen ve bir döneme sığdırılan pedagojik formasyon kurslarında verilen dersler, Tablo 7'de verilmiştir.

Tablo 7 pedagojik formasyon kurslarında verilen dersler

$\begin{array}{lc}\text { Ders } & \text { Kredi } \\ \text { Eğitim Bilimine Giriş } & 2-0-2 \\ \text { Gelişim Psikolojisi } & 2-0-2 \\ \text { Öğrenme Öğretme Kuram ve Yaklaşımları } & 2-0-2 \\ \text { Program Geliştirme ve Öğretim } & 2-0-2 \\ \text { Ölçme ve Değerlendirme } & 2-0-2 \\ \text { Sınıf Yönetimi } & 2-0-2 \\ \text { Öğretim Teknolojileri ve Materyal Tasarımı } & 2-2-3 \\ \text { Özel Öğretim Yöntemleri } & 3-2-4 \\ \text { Rehberlik } & 2-0-2 \\ \text { Öğretmenlik Uygulaması } & 2-6-5 \\ \text { Toplam } & \mathbf{2 1 - 1 0 - 2 6}\end{array}$

Tablo 7'den görüldüğü gibi, Öğretmenlik Uygulaması dışında kursta verilen derslerin kredisi 21'dir. Bu değer, bölümlere göre programlarda seçmeli dersler bulunsa da, 19371953 programı dolayında ama 1970-1974 programından çok düşüktür. Pedagojik 
formasyon kurslarında 7 haftada verilen bu dersler, kısmen öğretilebilse de öğretmenlik bilincinin verilmesi mümkün değildir.

1973 yılında çıkarılan ve Türk Eğitim Sisteminin Anayasası olarak kabul edilen 1739 sayılı Milli Eğitim Temel Kanunu'nun 43. Maddesinde Öğretmenlik mesleği, devletin ĕgitim, ögretim ve bununla ilgili yönetim görevlerini üzerine alan özel bir ihtisas mesleği olarak tanımlanmıştır. Bu ihtisas mesleğinin 7 haftalık yoğunlaştırılmış bir kursla verilemeyeceği açıktır.

Ülkelerin geleceğini oluşturan öğretmenlerin en iyi şekilde eğitilmeleri gerekir. Bu konuda ülkeler gerekli önlemleri almaktadır. Örneğin; Fransa'da öğretmen eğitimi 1990'lı yılların başında önemli bir değişim geçirmiştir. 1990 öncesi dönemde ilköğretim ve ortaöğretim öğretmenleri farklı kurumlarda ve ayrı birimler tarafından yetiştirilmekteydi. İlköğretim öğretmenleri, Eğitim Bakanlığına bağlı öğretmen okullarında (Ecoles Normales) yetiştirilmekteydi. Ortaöğretim öğretmenleri ise, üniversitelerde gördükleri alan eğitiminden sonra öğretmenlik sınavlarına hazırlık amacıyla bir yıl meslekî eğitim alıyorlardı. 1989 yılında başlatılan bir reformla ilköğretim ve ortaöğretim öğretmenlerinin eğitimlerini săglayacak Öğretmen Yetiştirme Enstitüleri (Institut Universitaire de Formation des Maitres - IUFM) kurulmuştur. Bu reformun temel amaçlarından birisi özellikle ortaöğretim öğretmeni yetiştirmede eksikliği hissedilen mesleki eğitimin güçlendirilmesidir. IUFM'lerde alan eğitiminden çok mesleki eğitim ön plana çıkmıştır. Yükseköğretim düzeyindeki bu enstitüler üniversiteler ile işbirliği içinde olsalar da, başlangıçta onların dışında özerk bir yapıya sahiplerdi. Ancak 2005 yılında yapılan bir değişiklikle öğretmen eğitimi veren IUFM'ler üniversite bünyesine alınmışlardır.

Fransız öğretmen yetiştirme sisteminde öğretmen seçme sınavları çok önemli bir rol oynamaktadır. Öğretmen yetiştiren kurumlar, öğrencilerini ortaöğretimden sonra değil, belirli bir üniversite eğitiminden (en az üç yıllık bir lisans eğitimi) sonra almaktadır. Yani öğretmenler alan eğitimini esas olarak öğretmen yetiştiren kurumlara girmeden önce almaktadır. Öğretmen adayları oldukça zor ve seçici bir sınav sonucunda, stajyer öğretmen olarak IUFM'lerde bir yıl mesleki eğitim görmektedir. IUFM'ler ayrıca bu sınavlara hazırlık eğitimi de vermektedir. Böylece öğretmen adayları IUFM'lerde bir yılı sınavlara hazırlık, bir yılı da asıl mesleki eğitim olmak üzere iki yıl eğitim almaktadır. Ancak sınava hazırlık eğitimi mecburi değildir. İsteyen adaylar bu eğitimi almadan da doğrudan sınava girebilir. Sınavları devletin öğretmen ihtiyacına göre sınırlı sayıda aday kazanmakta ve bir y1llık mesleki eğitimi başarıyla tamamlayanlar öğretmen olarak doğrudan eğitim kurumlarına atanmaktadır (Uygun vd., 2011).

Tablo 8 Fransa'da yıllara göre öğretmen yetiştirme aşamaları

\begin{tabular}{|c|c|c|c|c|c|}
\hline & Lisans & $\begin{array}{l}\text { Enstitü } \\
\text { (IUFM) }\end{array}$ & Lisansüstü & Uygulama & Seçme sınavı \\
\hline 2008 öncesi & 3 y1l & $1 \mathrm{y} 1 \mathrm{l}$ & isteğe bağlı & $1 \mathrm{y} 1 \mathrm{l}$ & lisans bitiminde \\
\hline 2008-2011 & 3 yil & $1 \mathrm{y} 1 \mathrm{l}$ & 2 yil & 1 yıl maaşlı aday & $\begin{array}{l}\text {-ön eleme } \\
\text {-seçme }\end{array}$ \\
\hline $2012-2013$ & 3 y1l & & 2 y1l & $\begin{array}{l}\text { lisans } 1 \text { sonundan } \\
\text { itibaren }\end{array}$ & $\begin{array}{l}\text {-seçme sinavi } \\
\text {-mesleğe giriş } \\
\text { sınav1 }\end{array}$ \\
\hline
\end{tabular}

Almanya'nın siyasal yapılanmasına uygun olarak öğretmen eğitimi eyaletlere bağlıdır. Eyaletler arası denklikleri sağlamak ve eyaletler üstü konularda kararları almak ise "Düzenli Kültür Bakanları Heyeti”nin sorumluluğundadır. Öğretmen yetiştirmede aşamalı bir model öngörülmüştür. Öğretmen eğitimi veren kurumların süresi 3 veya 4 yıl kuramsal, 2 y1l uygulama ağırlıklı olmak üzere toplam beş veya altı yıl; ortaöğretim öğretmenliği (Gymnasium) için $5+2$ veya $6+2$ yıl şeklinde toplam yedi ya da sekiz yıldır. 
Öğretmen adayları, bazı eyaletlerdeki istisnalar dışında, genelde "Eğitim Bilimleri Fakülteleri"nde (Erziehungswissenschaftliche Fakultät) yetiştirilmektedir (Uygun vd., 2011).

İngiltere'de öğretmenler, eğitim kolejleri veya öğretmen yetiştiren fakülteler veya bölümlerden yetiştirilir. Bunun için adaylara alan bilgisi, genel kültür ve öğretmenlik mesleğine ilişkin kuramsal dersler ile uygulamalı öğretim etkinlikleri verilir. İlköğretim öğretmenliği adayları en az 25 hafta, ortaöğretim öğretmenliği adayları ise en az 32 hafta öğretmenlik uygulamasına gider (Albayrak, 2011).

Finlandiya'da öğretmen olabilmek için sadece üniversite giriş sınavı yeterli değildir. Üniversite giriş sınavında başarı olan öğrenciler öğretmen olabilmek için yazılı giriş sınavı, yetenek testi, bireysel mülakat ve grup tartışması aşamalarından geçmek zorundadır. $\mathrm{Bu}$ sınavların içerikleri üniversiteden üniversiteye farklılık göstermektedir (Eraslan, 2009).

Güney Kore'de öğretmenlerin mezun olduktan sonra yüksek lisans veya doktora programlarını bitirme zorunlulukları yoktur. Her ne kadar öğretmenlik sertifikası alabilmek için sınava tabi tutulmasalar da devlet kurumlarında öğretmenlik yapabilmek için öğretmen yerleştirme sınavına girmek durumundadırlar. Alınan puanlar en yüksekten en düşüğe doğru sıralanarak öğretmen adayları kontenjanlar dâhilinde devlet okullarına yerleştirilmektedirler. Sınavın \%30'unu ilk aşama genel eğitim derslerini ölçmeye yönelik hazırlanmış test sunulurken, ikinci aşaması alan ve meslek bilgisiyle ilgili açık uçlu sorular ve görüşme oluşturmaktadır. Sınavı kazansa bile öğrencinin mülakata alınıp öğretmenlik tutumunun ölçülmesi öğretmenlik mesleğini yerine getirebilmede belirli niteliklere sahip olması gerektiğini ve bunun meslek için önemli olduğunu göstermektedir (Aras ve Sözen, 2012).

Türkiye'de öğretmenlik mesleğinin saygınlığ 1970'li yıllara kadar korunmuş, ancak daha sonra ülkemizdeki hızlı toplumsal, siyasal değişme ve sanayileşme ile birlikte giderek gerilemeye başlamıştır. 1980'li yıllarda yeni meslek gruplarının ortaya çıkması, memurların gelir düzeylerinin giderek düşmesi ile birlikte öğretmenlik mesleği de eski saygınlığını giderek yitirmiş ve toplumsal statüdeki yeri aşağıya doğru düşmeye başlamıştır.

Bilindiği gibi, 1982 yılında yapılan değişiklikle öğretmen yetiştirme sorumluluğu Milli Eğitim Bakanlı̆̆ı'ndan alınarak, üniversitelere verilmiştir. Bu süre içerisinde, eğitim fakülteleri, eğitim sistemimizin gereksinimi olan nitelikli öğretmenleri yetiştirmede önemli katkılar sağlamışlardır. Eğitim fakültelerinin Ortaöğretim Fen ve Matematik Alanlar Eğitimi (OFMA) ile Ortaöğretim Sosyal Alanlar Eğitimi (OSA) bölümlerinde 5 yıllık eğitim alan başarılı lise öğretmenleri yetiştirilmiştir. Ancak 2013-2014 öğretim yılından itibaren bu bölümlere öğrenci alımı durdurulmuş ve lise öğretmeni olabilmek için tek kaynak fen-edebiyat fakültesi mezunlarına verilen 14 haftalık pedagojik formasyon kursu olarak belirlenmiştir.

\section{Sonuç ve öneri}

1923 yılında Fransa'nın École Normale Superieure adlı okulunu örnek alarak kurulan Yüksek Öğretmen Okulları ne yazık ki 1970'li yıllarda “mezunlar öğretmenlik yerine akademisyenliği seçiyor" bahanesi ile kapatılmıştır. Küçük yaştan itibaren öğretmenliğe hazırlanan mezunlar lise öğretmenlikleri dışında, akademik yaşantılarında da başarılı olmuşlardır. Fransa, École Normale Superieure dönemini yetersiz görüp, öğretmen yetiştirmede uzun süreli ve uygulamalı eğitime geçerken, ülkemizde Eğitim Fakültelerinin OFMA ve OSA bölümlerinin kapatılma aşamasında olması manidardır.

Tablo 1'de altı ana başlıkta verilen öğretmen yeterliklerine sahip öğretmen yetiştiren Yüksek Öğretmen Okullarının yeniden kurulması söz konusu değildir. Kapaılmış olanAnadolu Öğretmen Liseleri yeniden açılarak, gerçekten öğretmen olmak isteyen 
gençlere Yüksek Öğretmen Okulu modeli uygulanarak onların Eğitim Fakültelerinin OFMA ve OSA bölümlerinde burslu öğrenim görüp lise öğretmeni olmaları sağlanabilir. Vurgulanması gereken bir önemli husus da öğretmenlik uygulama saatlerinin arttırılmasıdır. Tek amacı Fen-Edebiyat Fakültesi mezunlarına istihdam yaratmak olan pedagojik formasyon kursları ise ilgili fakültere öğreci alımı azaltılarak durdurulabilir.

\section{Kaynakça}

Akyüz, Y. (2004). Türk Eğitim Tarihi (M.Ö.100- M.S.2004). Ankara: Pegem Yayıncılık. Aras, S. ve Sözen, S. (2012). Türkiye, Finlandiya ve Güney Kore'de öğretmen yetiştirme programlarının incelenmesi, X. Ulusal Fen Bilimleri ve Matematik Eğitimi Kongresi, Niğde.

Aycan N. ve Aycan Ş. (2013). A forsaken institution for teacher educate in Turkey: Higher Teachers' Training College, Conference of the International Journal of Arts and Sciences, Munich- Almanya.

Aycan, Ş. (2011). Yüksek Öğretmenli akademisyenlerin bakış açısıyla eğitim sorunları, Köy Enstitüleri, İlkögrretmen Okulları ve Yüksek Öğretmen Okulları Bağlamında Ülkenin Güncel Eğitim Sorunlarl, Çözüm Önerileri Sempozyumu, İzmir.

Aycan, Ş. ve Aycan, N. (2009). Yüksek Öğretmenli Kadın Akademisyenler, Uluslararası Multidisipliner Kadin Kongresi, Ekim 2009 İzmir.

Aycan, Ş. ve Aycan, N. (2011). İstendik davranışların kazandırılması eğitim midir? Hasan Âli Yücel'in Eğitim Anlayışı, Aramızdan Ayrılışının 50. Yılında Hasan-Ali Yücel'den Günümüze Ĕgitim, Bilim, Kültür Politikaları Sempozyumu, İzmir.

Aycan, Ş., Sağlam, Ö. ve Arslan, Z. K. (2010). Eğitim fakültesi ve fen edebiyat fakültesi öğrencilerinin öğretmenliğe karşı tutumları: Muğla Üniversitesi örneği, Türk Milli Ĕ̈itiminin Güncel Sorunlarl ve Önerileri Sempozyumu, Yalova.

Aycan, Ş., Aycan, N. ve Türkoğuz, S. (2005). Fen edebiyat fakültesi öğrencilerinin tezsiz yüksek lisans programlarından beklentileri ve kaygıları, Buca Eğitim Fakültesi Dergisi, Özel say1, 17, 17-24.

Başbay, M., Ünver, G. ve Bümen, N. T. (2009). Ortaöğretim alan öğretmenliği tezsiz yüksek lisans öğrencilerinin öğretmenlik mesleğine yönelik tutumları: boylamsal bir çalışma, Kuram ve Uygulamada Eğitim Yönetimi, 15 (59)59, 345-366.

Albayrak, O. (2011). Bir Meslek Olarak Öğretmenlik, Eğitim Bilimine Giriş Ders Notları, Malatya.

Bozkırlı, K. Ç. ve Er, O. (2011). Türkçe ve Türk Dili ve Edebiyatı öğretmen adaylarının ögretmenlik mesleğine ilişkin tutumlarının çeşitli değişkenler açısından incelenmesi (Kafkas Üniversitesi Örneği), Turkish Studies 6(4), 457-466.

Çelikten, M., Şanal, M. ve Yeni, Y. (2005). Öğretmenlik mesleği ve özellikleri, Sosyal Bilimler Enstitüsü Dergisi, 19 (2), 207-237.

Dündar, H. ve Karaca, E. T. (2013). Formasyon öğrencilerinin pedagojik formasyon programına ilişkin sahip oldukları metaforlar, Gazi Üniversitesi Endüstriyel Sanatlar Eğitim Fakültesi Dergisi, 30, 19-34.

Eraslan, A. (2009). Finlandiya'nın PISA'daki başarısının nedenleri: Türkiye için alınacak dersler, Necatibey Eğitim Fakültesi Elektronik Fen ve Matematik Eğitimi Dergisi, 3 (2), 238-248.

Eşme, İ. (2001). Yüksek Öğretmen Okulları. Bilgi- Başarı Yayınevi. İstanbul.

Eşme, İ. (2003). Öğretmen Yetiştirmede 130 Yılllk Bir Sürecin Öyküsü: Yüksek Öğretmen Okulları, Milli Ĕ̈itim Dergisi, 160 (http://dhgm.meb.gov.tr/yayimlar/dergiler/ Milli_Egitim__Dergisi/160/esme.htm)

Gelişli, Y., (2001). Öğretmen Yetiştirmede Ankara Yüksek Öğretmen Okulu Uygulaması, Milli Ĕ̈itim Dergisi, 149

(http://dhgm.meb.gov.tr/yayimlar/dergiler/Milli_Egitim_Dergisi/149/gelisli.htm) 
Gelişli, Y. (2009). Mesleki ve teknik eğitim fakülteleri öğrencilerinin pedagojik formasyon eğitimine ilişkin görüşleri, Gazi Üniversitesi Endüstriyel Sanatlar Eğitim Fakültesi Dergisi, 25, 76-89.

Güneş, G. ve Gökçek, T. (2012). Pedagojik formasyon öğrencilerinin öğrenme stilleri, Ĕgitim ve Öğretim Araştırmaları Dergisi, 1(4), 28-40.

Ilgaz, G., Bülbül, T. ve Çuhadar, C. (2013). Öğretmen adaylarının eğitim inançları ile öz yeterlik algıları arasındaki ilişkinin incelenmesi, Abant İzzet Baysal Üniversitesi Ĕgitim Fakültesi Dergisi, 13(1), 50-65.

Kavak, Y., Aydın, A. ve Altun, S. A. (2007). Öğretmen yetiştirme ve eğitim fakülteleri (1982-2007), YÖK yayınları, 2007/5, Ankara.

Ocak, G. ve Demirdelen, C. (2008). Eğitim fakültesi öğrencileri ile tezsiz yüksek lisans öğrencilerinin öğretmenlik mesleğine yönelik tutumlarının karşılaştırılmalı incelemesi, Erzincan Üniversitesi Ĕ̈itim Fakültesi Dergisi, 10(2), 151-171.

Öğretmen Yeterlikleri Özet Raporu (2009). Türk Eğitim Derneği, Ankara.

Özben, Ş. (2005). Tezsiz yüksek lisans öğrencilerinin öğretmenlik mesleğine ilişkin tutumlarının incelenmesi, Buca Eğitim Fakültesi Dergisi, 17, 37-43.

Özder, H., Konedralı, G. ve Zeki, C. P. (2010). Öğretmen adaylarının öğretmenlik mesleğine yönelik tutumlarının çeşitli değişkenler açısından incelenmesi, Kuram ve Uygulamada Ĕ̈itim Yönetimi, 16(2) 253-275.

Saydı, T. (2013). Fransa'da öğretmen yetiştirme alanında yükseköğretim reformu, Hacettepe Üniversitesi Eğitim Fakültesi Dergisi, Özel sayı (1), 327-343.

Uygun, S. (2006). Cumhuriyet Döneminde ortaöğretime öğretmen yetiştirme uygulamalarının tarihsel analizi, Ortä̈gretimde Yeniden Yapılandırma Sempozyumu, Ankara.

Uygun, S., Ergen, G. ve Öztürk, İ. H. (2011). Türkiye, Almanya ve Fransa'da öğretmen eğitimi programlarında uygulama eğitiminin karşılaştırılması, İlköğretim Online, 10 (2) 389-405.

Ünüvar, S. (2012). Fen-Edebiyat fakülteleri ve formasyon programı (öğretmen yetiştirme), 21. Yüzyllda Ĕ̈itim veToplum Bilimleri ve Sosyal AraştırmalarDergisi, 1(2) 97-104.

Yüksel, S. (2011). Fen-Edebiyat fakültesi öğretim üyelerinin öğretmen yetiştirme sistemine ilişkin düşünceleri (Uludağ Üniversitesi Fen- Edebiyat Fakültesi örneği), Kuram ve Uygulamada Ĕgitim Bilimleri, 11(1), 179-198.

http://www.muallimce.com/ (10.01.2014).

http://tr.wikipedia.org/wiki/\%C3\%89cole Normale Sup\%C3\%A9rieure (10. 01. 2014). http://otmg.meb.gov.tr/YetGenel.html (10. 01. 2014).

Yazar

Prof. Dr. H. Şule Aycan

E-mail: suleaycan@mu.edu.tr 